\title{
The Effect of Institutional Ownership, Leverage, and Profitability on Firm Value: Dividend Policy as an Intervening Variable
}

Teguh Gunawan Setyabudi ${ }^{*}$,

${ }^{1}$ Sekolah Tinggi Ilmu Ekonomi Indonesia Surabaya, Indonesia

\begin{tabular}{ll}
\hline ARTICLE INFO & ABSTRACT \\
\hline ISSN: 2723-1097 & $\begin{array}{l}\text { The existence of competition requires companies to make various efforts to maintain } \\
\text { the existence of the company and increase company value. The company value is } \\
\text { indicated by the company's stock price. The purpose of this research is to prove } \\
\text { empirically the effect of profitability, leverage and institutional ownership on firm } \\
\text { value with dividend policy as an intervening variable. The research data is }\end{array}$ \\
firm value; institutional & $\begin{array}{l}\text { secondary data in the form of financial statement data and annual reports of } \\
\text { companies belonging to the manufacturing industry listed on the Indonesia Stock } \\
\text { ownershi; profitability; } \\
\text { leverage; dividend policy } \\
\text { Eath analysis. The results showed that profitability, leverage and institutional } \\
\text { ownership had a significant effect on dividend policy. The variables of profitability, } \\
\text { leverage and dividend policy are proven to have a significant effect on firm value, } \\
\text { while institutional ownership has no effect on firm value. The dividend policy } \\
\text { variable is able to moderate the effect of profitability on firm value, but it is not able } \\
\text { to moderate the effect of leverage and institutional ownership on firm value. }\end{array}$ \\
\hline
\end{tabular}

\section{Introduction}

A business entity at the time of its establishment must have a predetermined purpose. Some of the objectives of establishing a company include: obtaining optimal profit, prospering shareholders (owners), and increasing company value. Firm value is a reflection of the addition of the company's equity and total debt (Rubiyani, 2016). The value of the company is important for potential investors in the stock exchange because it is an indicator to assess the company as a whole. Firm value is the company's performance as reflected in the stock price, which is formed from supply and demand in the capital market and as a reflection of the public's assessment of the company's performance (Harmono, 2009). If the stock price of a company is high, then the value of the company is also high. The increasing value of the company is indicated by the increase in stock prices, which is marked by a high rate of return for shareholders, this reflects that the value of the company is believed to be able to describe current performance and future performance (Wihardjo, 2014).

Journal of Business and Management Review Vol. 2 No. 72021 Page 457-469

DOI: $10.47153 /$ jbmr27.1632021

*Corresponding Author

Email address: teguhgunawan@stiesia.ac.id 
The company's financial performance is one of the factors seen by potential investors in determining stock investment. Financial performance can be measured through the calculation of financial ratios whose information is contained in the company's financial statements, these ratios are designed to assist investors or analysts in evaluating a company based on its financial statements (Horne and Wachowicz, $\underline{2005}$ ). Financial statements are used for useful decision making. Financial reports contain quality information for its users. Investors or analysts usually use financial ratios, including among others: leverage and profitability (Riyanto, 2001). Profitability describes the company's ability to generate profits at a certain level of sales, assets, and share capital (Sitepu, 2010). Before deciding to invest, potential investors need to look at the return on equity of a company in order to know how much will be generated from the investment. The higher the ROE indicates that the higher the rate of return on the investment made and the lower the ROE of a company, the lower the rate of return will be.

Leverage describes the company's ability to pay or fulfill its obligations with its own capital. Leverage in this study is represented by debt to equity ratio (DER). DER is a ratio that compares total debt with total equity. Total debt includes current liabilities and long-term liabilities. The larger the DER ratio indicates the capital structure is also getting bigger as stated by Sitepu (2010) that the smaller the DER ratio, the better the company's ability to survive in bad conditions.

Dividend policy can affect firm value because dividend policy relates to the use of profits which are the rights of investors. The company's profits can be divided as dividends or become retained earnings which will be used for company operations. Each company has a different dividend policy, because the company must be able to consider the amount of profit to be retained to develop the company Nurmala (2006) An increase in dividends can reduce agency costs. A reflection of the high value of the company can be seen from the small amount of agency conflict. Agency conflicts arise between shareholders as principal and management as executor. Jensen and Meckling (1976), shareholders try to supervise managers so that the company can run according to their wishes.

In the bird in the hand theory related to dividend policy, the company's cost of capital will increase if the dividend payout ratio is low because investors prefer dividends over capital gains, dividend yields are considered safer. Dividend policy as a moderating variable of the influence of profitability and leverage on firm value, this is because dividend policy is the center of attention of many parties such as shareholders, creditors, and other external parties who have an interest in the information issued by the company (Erlangga, 2009). The greater the dividends distributed to shareholders, the better the company's performance will be, and in the end the assessment of the company reflected in the share price will be even better (Erlangga, 2009). Widyasari (2020) examines the analysis of factors that affect firm value. Profitability and firm age have a positive effect on firm value, while leverage and dividend policy have no effect on firm value. Research by Widayanti and Yadnya 
(2020) found that leverage and profitability have a positive effect on firm value. Meanwhile, dividend policy has no effect on firm value (Husna and Rahayu, 2020).

The existence of a research gap from some of the research results above, motivates researchers to re-examine the factors that affect firm value. The study was conducted on manufacturing companies in the period 2016 to 2018. Researchers took samples from manufacturing companies because the manufacturing industry has quite fierce competition and various types of companies for company assessment. This study aims to examine and obtain empirical evidence of the effect of institutional ownership, leverage, profitability, and dividend policy on firm value.

\section{Literature Review}

Agency Theory

Jensen and Meckling (1976), agency theory is the relationship between the agent and the principal, where the agent provides a service on the assignment of the principal and principal and then delegates decision-making authority to the agent. Agents and principals have different interests. Management has a goal to prosper its own welfare, while the principal has a goal to increase his wealth. The existence of different interests can lead to a conflict of interest. The conflict raises agency costs or agency costs. Agents and principals of course want to reduce agency costs (Jensen and Meckling, 1976). Anthony and Govindarajan (2005) agency theory has the assumption that each individual is solely motivated by his own interests, thus creating a conflict of interest between the agent and the principal. Delegation of authority to run the entity, making management performance shown through profitability and leverage ratios will have an impact on dividend distribution and increase company value.

\section{Firm Value}

The value of the company shows a condition that has been achieved by the entity as an illustration of public trust in the company (Noerirawan, 2012). Maximizing the value of the company which is reflected in its share price is the goal of the company. The higher the stock price of a company, the higher the value of the company. If the company has a high value, this is the desire of the owners of the company, because a high value will indicate the high prosperity of shareholders. The value of the company is the valuation of the company by investors which is often related to the stock price. Firm value is measured by the ratio Price to Book Value (PBV). PBV describes how much the market appreciates the book value of a company's shares (Subramanyam, $\underline{2014})$.

\section{Institutional Ownership}

Agency costs arise due to agency conflicts. The low agency cost can increase the value of the company. Jensen and Meckling (1976), institutional ownership structure and managerial ownership structure have an important impact on the company's 
control system. The level of institutional ownership is measured by dividing the shares owned by institutional shareholders by the number of shares outstanding.

\section{Leverage}

Leverage describes the company's ability to meet its obligations with its own capital. Leverage in this study is represented by debt to equity ratio (DER). DER is a ratio that compares total debt with total equity. Total debt includes current liabilities and long-term liabilities. DER shows the relationship between the number of loans granted by the owner of the company.

Leverage is a financial ratio that has a relationship with the company's funding composition. Leverage is measured by the ratio of Book Debt to Equity Ratio (BDE). BDE compares the amount of debt to the total equity of the company. This ratio can have a positive or negative effect on the profitability of the company's own capital (Sugiono and Untung, 2016).

\section{Profitability}

Profitability describes the company's ability to generate profits at a certain level of sales, assets, and share capital ( $\underline{\text { Sitepu, 2010)}})$, before deciding to invest, potential investors can see the return on equity (ROE) of a company entity to find out how much will be earned on investment. that is implanted. Brigham and Houston (2001), profitability shows the ability to generate returns on activities that occur in an accounting period. The profit generated by the company is high, of course, it can affect the company's stock price. The high stock price of a company is a reflection of the high value of the company as well.

Profitability is the company's ability to generate profits. In this study, the profitability variable was measured using the Return On Equity (ROE) ratio. ROE measures the rate of return of the business on all existing capital. ROE can also be referred to as Profitability of Own Capital (Sugiono and Untung, 2016).

\section{Dividend Policy}

Dividends are part of the profits obtained by the company and distributed to shareholders as a reward for their willingness to invest (Rudianto, 2009). Management makes a dividend policy, where this policy involves two different interests, namely the owners (shareholders) and management itself (Wijaya and Seanda, 2015). Dividend policy relates to the use of profits that are the rights of investors. The company's profits are classified into profits that can be distributed called dividends and retained earnings, namely profits that will be used for investment and company operations. Dividend policy is a policy of distributing dividends to shareholders on the profits generated by the company in one period. 
The portion of profits distributed to shareholders is known as dividends. Companies with profits will distribute dividends to company owners. According to Brigham and Houston (2001) revealed that companies that are able to generate high profits are able to pay high dividends as well. According to Septiana (2015) stated that profitability is one of the factors that influence dividend policy and profitability has a positive and significant effect on dividend policy. Wijaya and Seanda (2015) show a significant effect of profitability on dividend policy in a positive direction. The higher the profit generated by the company, the higher the opportunity for the company to pay dividends. The profit obtained by large companies, the greater the share of the profit paid (Ifafah and Suryono, 2020). From the several studies above, the following hypotheses can be formulated:

H1: Profitability has a positive effect on dividend policy.

The Effect of Leverage on Dividend Policy

Based on agency theory (Jensen and Meckling, 1976) there are several factors that can reduce agency costs, namely leverage and dividend policy. Leverage is used by companies to measure how much assets the company owns from debt or capital. Based on research from Sulistyowati et al. (2014) states that leverage has a significant effect on dividend policy. Based on the theory and research, the following hypotheses can be formulated:

$\mathrm{H} 2$ : Leverage has a positive effect on dividend policy.

The Effect of Institutional Ownership on Dividend Policy

According to Jensen and Meckling (1976), the higher the ownership structure controlled by management or the smaller it is controlled by outside management, the less agency conflict, because the more aligned the interests of management with the interests of the owners, most of which are management itself. In this case the less dependence on dividends as a monitoring mechanism. Darminto (2008) states that ownership structure has a positive effect on dividend policy. From the several studies above, the following hypotheses can be formulated:

H3: Institutional ownership has a positive effect on dividend policy.

The Effect of Profitability on Firm Value

Research Putra (2014), Safitri et al. (2014), Hasibuan et al. (2016) and Suryanti and Amanah (2020) empirically prove that profitability has a positive and significant effect on firm value. This shows that companies with high profitability will be followed by high company values. Companies with increased profits generate positive sentiment from shareholders because their performance is considered good and has an impact on increasing share prices and company value (Wijaya and Seanda, 2015). Husna and 
Rahayu's research (2020) measures profitability with Return on Assets (ROA) having an influence on firm value. Mahendra's research (2011) proxied profitability by Return On Equity. ROE can determine the company's ability to generate profits through its own capital. The higher the profit generated, the higher the share of dividends distributed. High profits can affect the value of the company. From the several studies above, the following hypotheses can be formulated:

H4: Profitability has a positive effect on firm value.

The Effect of Leverage on Firm Value

According to Jensen and Meckling (1976) stated that the existence of debt, the agency costs will be smaller. A small agency cost will increase the value of the company. According to Jensen and Meckling (1976) stated that debt can reduce the free cash flow that is in the company, so that the risk of fraud that can be carried out by the management (agent) can be reduced. Research conducted by Hasibuan et al. (2016), Widayanti and Yadnya (2020) state that leverage has a significant positive effect on firm value. From the several studies above, the following hypotheses can be formulated:

H5: Leverage has a positive effect on firm value.

The Effect of Institutional Ownership on Firm Value

Jensen and Meckling (1976) mention that ownership structure can influence agency conflict. Companies that have high managerial ownership can minimize the agency costs that arise. A small agency cost can increase the value of the company. The ownership structure also underlies the dividend distribution policy carried out by the company. Most of the outstanding shares owned by the public tend to want a high dividend distribution as a return on their investment. From the several studies above, the following hypotheses can be formulated:

H6: Institutional ownership has a positive effect on firm value.

The Effect of Dividend Policy on Firm Value

High dividend distribution is a positive signal for investors who have invested their wealth. High dividends can increase investor expectations so that it can indirectly increase stock prices. The stock price is a reflection of the value of the company. The results of research from Wijaya (2010) states that dividend policy has a significant positive effect on firm value. The greater the amount of dividends distributed will affect the response to changes in stock prices so that the value of the company also increases (Wijaya and Seanda, 2015). Based on some of the research above, the following hypotheses can be formulated:

H7: Dividend policy has a positive effect on firm value.

\section{Method}


This research is a quantitative research. Quantitative data used is sourced from secondary data obtained from the Indonesia Stock Exchange and the company's official website. Secondary data is in the form of financial statements of manufacturing companies listed on the Indonesia Stock Exchange in the 2016-2018 period. The population of this study are manufacturing companies listed on the Indonesia Stock Exchange in the 2016-2018 period. The sample was selected using purposive sampling with the following criteria: (1) Manufacturing companies listed on the Indonesia Stock Exchange in the period 2016 - 2018; (2) The company's financial statements for the period January 1 to December 31; (3) The company's financial statements are available at www.idx.co.id or the company's website.

\section{Result and Discussion}

\section{Research Object Overview}

The research data comes from the financial statements and annual reports of companies belonging to the manufacturing industry sector listed on the Indonesia Stock Exchange in the period 2016 - 2018. According to the data obtained from the Indonesia Stock Exchange, companies that meet the criteria in 2016 to 2018 are 138 companies.

The Goodnest of fit test

The result of the goodnest of fit test (F test) are shown in the following table:

Table 1. F. Test Result

\begin{tabular}{lll}
\hline del & F & Sig. \\
\hline 1 & 16,566 & 0,000 \\
2 & 29,071 & 0,000 \\
\hline
\end{tabular}

Source: processed data, 2021

Coefficient of Determination $\left(\mathrm{R}^{2}\right)$

Measurement of the coefficient of determination is carried out with the aim of measuring how far the model's ability to explain the dependent variable (Ghozali, 2006). The value of the coefficient of determination is between 0 and 1 . The results of the coefficient of determination test can be seen in the following table.

Table 2. Coefficient of Determination $\left(\mathbf{R}^{2}\right)$

\begin{tabular}{cc}
\hline Model & $\mathrm{R}^{2}$ \\
\hline 1 & 0,254 \\
2 & 0,450 \\
\hline
\end{tabular}


Source: processed data, 2021

\section{Path analysis}

To determine the direct and indirect effect of the independent variable to the dependent variable, in the following table.

Table 3. Path analysis

\begin{tabular}{|c|c|c|c|c|c|}
\hline \multirow{2}{*}{$\begin{array}{l}\text { Hypothesis } \\
\text { No. }\end{array}$} & \multirow[t]{2}{*}{ Path Analysis } & \multirow[t]{2}{*}{ Sig. } & \multicolumn{2}{|c|}{ Efect } & \multirow[t]{2}{*}{ Total } \\
\hline & & & Direct & $\begin{array}{c}\text { Indir } \\
\text { ect }\end{array}$ & \\
\hline 1 & $\begin{array}{c}\text { Profitability } \rightarrow \text { Dividend } \\
\text { Policy }\end{array}$ & $\left.0,000^{*}\right)$ & 0,959 & - & 0,959 \\
\hline 2 & Leverage $\rightarrow$ Dividend Policy & $\left.0,000^{*}\right)$ & $-0,058$ & - & $-0,058$ \\
\hline 3 & $\begin{array}{c}\text { Institutional Ownership } \rightarrow \\
\text { Dividend Policy }\end{array}$ & $\left.0,014^{*}\right)$ & $-1,517$ & - & -1517 \\
\hline 4 & Profitability $\rightarrow$ Firm Value & $\left.0,000^{*}\right)$ & 18,546 & - & 18,546 \\
\hline 5 & Leverage $\rightarrow$ Firm Value & $\left.0,007^{*}\right)$ & $-0,548$ & - & $-0,548$ \\
\hline 6 & $\begin{array}{c}\text { Institutional Ownership } \rightarrow \\
\text { Firm Value }\end{array}$ & $\begin{array}{c}0,512 \\
\left.0,022^{*}\right)\end{array}$ & $-4,957$ & - & $-4,957$ \\
\hline 7 & Dividend Policy $\rightarrow$ Firm Value & & 2,422 & - & 2,422 \\
\hline 8 & $\begin{array}{l}\text { Profitability } \rightarrow \text { Dividend } \\
\text { Policy } \rightarrow \text { Firm Value }\end{array}$ & - & - & $\begin{array}{l}0,959 x \\
2,422\end{array}$ & 2,322 \\
\hline 9 & $\begin{array}{c}\text { Leverage } \rightarrow \text { Dividend Policy } \\
\rightarrow \text { Firm Value }\end{array}$ & - & - & $\begin{array}{c}- \\
0,058 x \\
2,422\end{array}$ & $-0,133$ \\
\hline 10 & $\begin{array}{c}\text { Institutional Ownership } \rightarrow \\
\text { Dividend Policy } \rightarrow \text { Firm Value }\end{array}$ & - & - & - & - \\
\hline
\end{tabular}

Source: processed data, 2021

The Effect of Institutional Ownership on Dividend Policy

The results of the analysis using SPSS prove that institutional ownership has an effect on dividend policy. The significance level obtained is 0.014 (sig. $<5 \%$ ). These results do not support hypothesis which states that institutional ownership has an influence on dividend policy received. The results of this study differ from those of Kurniawati et al. (2015) and Sutanto et al. (2017) who found that institutional ownership has a significant positive effect on dividend policy.

The Effect of Leverage on Dividend Policy

The results of the analysis using SPSS prove that leverage has an effect on dividend policy. The significance level is 0.000 (sig. $<1 \%$ ). These results do not support 
hypothesis which states that leverage has a positive effect on dividend policy received. The results of this study support the results of research by Jayanti et al. (2021) and Maharani (2021) who argue that leverage has a significant negative effect on dividend policy. Meanwhile, the results of the study do not support the research shown by Sulistyowati et al (2014) which shows that leverage has an effect on dividend policy. The higher the leverage, the more debt the company's management uses to run the company's operations. The high level of corporate debt makes the company focus on paying debts so that it is unable to pay dividends. The high risk of corporate debt can cause the company not to distribute dividends to shareholders.

\section{The Effect of Profitability on Dividend Policy}

The results of the analysis using SPSS prove that profitability has an influence on dividend policy. The significance level is 0.000 (sig. $<1 \%$ ). These results support hypothesis that profitability has a positive effect on dividend policy received. The results of this study support research from Septiana (2015), Wijaya and Seanda (2015), Ifafah and Suryono (2020), Jayanti et al. (2021) and Maharani (2021), which state that profitability has a significant positive effect on dividend policy. Meanwhile, the results of this study do not support the research of Deviana and Fitria (2017) and Rais and Santoso (2017), profitability has no effect on dividend policy. The results of this study indicate that the higher the company's ability to earn profit, the higher the portion of dividend distribution.

\section{The Effect of Institutional Ownership on Firm Value}

The results of the analysis using SPSS show that institutional ownership has no significant effect on firm value. The significance level is 0.512 (sig. $>5 \%$ ). These results support the research of Rudianti et al. (2020) which states that institutional ownership has no significant effect on firm value. However, the results of this study do not support the research of Anggita et al. (2021), Cristofel and Kurniawati (2021) and Riyanti and Munawaroh (2021) who state that institutional ownership has a significant positive effect on firm value. Research by Yudistira et al. (2021) stated that institutional ownership has a significant negative effect on firm value.

\section{The Effect of Leverage on Firm Value}

The results of the analysis using SPSS prove that leverage has an effect on firm value. The significance level was 0.007 ( $\mathrm{sig}$. <1\%). These results do not support hypothesis which states that leverage has a positive effect on firm value. This study supports the results of Maharani's (2021) study which states that leverage has a significant negative effect on firm value. The higher the leverage, the more debt the company's management uses to run the company's operations. A high level of corporate debt makes the company focus on paying off debt, causing investors to be less interested in the company or it can be said that the value of the company decreases.

The Effect of Profitability on Firm Value 
The results of the analysis using SPSS prove that profitability has an influence on firm value. The significance level is 0.000 (sig. $<1 \%$ ). These results support hypothesis which states that profitability has a positive influence on the firm value received. This study supports Safitri et al. (2014), Hasibuan et al. (2016), Suryanti and Amanah (2020), Anggita et al. (2021) and Maharani (2021) who stated that profitability had a significant and positive influence on firm value. From the investor's point of view, companies with the ability to earn high profits are able to increase shareholder returns.

\section{The Effect of Dividend Policy on Firm Value}

The results of the analysis using SPSS prove that dividend policy has an influence on firm value. Significance level 0.022 (sig. $<5 \%$ ). The results of this study are not in line with the research of Yudistira et al. (2021) which proves that dividend policy has no effect on the value of manufacturing companies. However, the results of this study support research from Wijaya (2010), Nofrita (2013), Mahendra (2011), Riyanti and Munawaroh (2021) which state that dividend policy has a significant effect on firm value.

\section{Conclusion}

This study aims to examine the firm value which is influenced by profitability, leverage, institutional ownership and dividend policy. This study uses 138 samples from companies that are members of the manufacturing industry on the Indonesia Stock Exchange with the research period from 2016-2018. The results of this study indicate that the effect of profitability proxied by ROE on Dividend Policy proxied by the DPR. The effect of leverage as proxied by BDE on Dividend Policy proxied by DPR shows that leverage has an effect on dividend policy. The effect of institutional ownership proxied by IOWN on Dividend Policy proxied by the DPR shows that institutional ownership has an influence on Dividend Policy.

The results of the research on the effect of profitability proxied by ROE on firm value proxied by PBV obtained the results that profitability had an effect on firm value. The results of the study of the effect of leverage proxied by BDE on firm value proxied by PBV showed that leverage had an effect on firm value. The results of the study of the effect of institutional ownership as proxied by IOWN on firm value as proxied by PBV showed that institutional ownership had no effect on firm. The effect of dividend policy proxied by the DPR on firm value as proxied by PBV obtains that dividend policy results have an effect on firm value. The dividend policy by the company will get a response from shareholders and have an impact on increasing the value of the company. From the research results obtained evidence that dividend policy is able to mediate the effect of profitability on firm value (H8 is accepted). This is supported by the standardized beta value. Empirical evidence shows that dividend policy is not able to mediate the effect of leverage on firm value (H9 is rejected). Hypothesis 10 is rejected that dividend policy is not able to mediate the effect of institutional ownership on firm value. 
Based on the results of the study, the researchers gave the following suggestions: 1) This study only uses samples from companies that are included in the manufacturing industry from 2016 to 2018. Therefore, for further research, it is necessary to increase the number of samples used. The more data used, it is hoped that the results obtained in the study will be more valid. The sample can use cross-industry or cross-country companies. 2) For further researchers, they should use several measurements to increase the accuracy of the measurement of each variable. For example, for the company value variable, in addition to using the Price to Book Value (PBV) ratio, you can use Tobin's $Q$ and other measurements. For the profitability variable, the Return on Asset (ROA) variable and other measurements can be used.

\section{References}

Anggita, R. T., R. Rinofah, and P. P. Sari. 2021. Pengaruh Kepemilikan Institusional, Kebijakan Hutang, Keputusan Investasi dan Profitabilitas Terhadap Nilai Perusahaan. Journal of Management, Accounting, Economic and Business 2 (1):38-49. Anthony and Govindarajan. 2005. Management Control System. Penerbit Salemba Empat. Jakarta.

Brigham, E. F. and J. F. Houston. 2001. Manajemen Keuangan. Edisi 8. Penerbit Erlangga. Jakarta.

Cristofel and Kurniawati. 2021. Pengaruh Enterprise Risk Management, Corporate Social Reesponsibility dan Kepemilikan Institusional Terhadap Nilai Perusahaan. Jurnal Akuntansi Bisnis 14 (1)

Darminto. 2008. Pengaruh Profitabilitas, Likuiditas, Struktur Modal dan Struktur Kepemilikan Saham Terhadap Kebijakan Dividen. Jurnal Ilmu Sosial 20 (2): 87-97.

Deviana, N. and A. Fitria. 2017. Pengaruh Profitabilitas dan Keputusan Investasi Terhadap Nilai Perusahaan Melalui Kebijakan Dividen. Jurnal Ilmu and Riset Akuntansi. 6 (3). ISSN: 2460-0585.

Erlangga, E. 2009. Pengaruh Kinerja Keuangan terhadap Nilai Perusahaan dengan Pengungkapan CSR, Good Corporate Governance dan Kebijakan Dividen sebagai Variabel Pemoderasi. Skripsi. Universitas Muhammadiyah Yogyakarta. Yogyakarta.

Harmono. 2009. Manajemen Keuangan Berbasis Balanced Scorecard (Pendekatan Teori, Kasus and Riset Bisnis). Bumi Aksara. Jakarta.

Hasibuan, V., M. Dzulkirom, and N. G. W. Enandg. 2016. Pengaruh Leverage dan Profitabilitas Terhadap Nilai Perusahaan (Studi pada Perusahaan Property dan Real Estate yang Terdaftar di Bursa Efek Indonesia Periode Tahun 2012-2015). Jurnal Administrasi Bisnis 39 (1).

Horne, J. C. V. and J. M. Wachowicz. 2005. Fundamentals of Financial Management. Prentice Hall. New York.

Husna, R. and Y. Rahayu. 2020. Pengaruh Pertumbuhan Perusahaan, Kebijakan Dividen dan Profitabilitas Terhadap Nilai Perusahaa. Jurnal Ilmu and Riset Akuntansi 9 (1).

Ifafah, A. A. and B. Suryono. 2020. Pengaruh Profitabilitas, Free Cash Flow, dan 
Likuiditas Terhadap Kebijakan Dividen. Jurnal Ilmu and Riset Akuntansi.

Jayanti, K. W. D., I. K. Sunarwijaya, and M. S. P. Adiyadnya. 2021. Pengaruh Likuiditas, Profitabilitas, Leverage, Pertumbuhan, Ukuran Perusahaan Terhadap Kebijakan Dividen Perusahaan Perbankan di Indonesia. Karya Riset Mahasiswa Akuntansi 1 (1): 309-317.

Jensen, M. C. and W. H. Meckling. 1976. Theory Of The Firm: Managerial Behaviour, Agency Cost, and Ownership Structure. Journal of Financial Economics 3: 305-360.

Kurniawati, L., S. Manalu, and R. J. N. Octabianus. 2015. Pengaruh Kepemilikan Institusional Terhadap Kebijakan Dividen dan Harga Saham. Jurnal Manajemen 15 (1): 59-73.

Maharani, I. A. D. P. 2021. Pengaruh Rasio Profitabilitas, Leverage dan Kebijakan Dividen Terhadap Nilai Perusahaan (Studi pada Sektor Perbankan di Bursa Efek Indonesia. Jurnal Widya Manajemen 3 (1): 27-38.

Mahendra, A. 2011. Pengaruh Kinerja Keuangan Terhadap Nilai Perusahaan dengan Kebijakan Dividen Sebagai Variabel Moderating pada Perusahaan Manufaktur di Bursa Efek Indonesia. Tesis. Universitas Udayana. Denpasar.

Noerirawan, R. 2012. Pengaruh Faktor Internal dan Eksternal Perusahaan Terhadap Nilai Perusahaan. Jurnal Akuntansi 1 (2).

Nofrita, R. 2013. Pengaruh Profitabilitas Terhadap Nilai Perusahaan Dengan Kebijakan Deviden Sebagai Variabel Intervening (Studi Empiris pada Perusahaan Manufaktur Yang Terdaftar di BEI). Skripsi. Universitas Negeri Paandg. Paandg.

Nurmala. 2006. Pengaruh Kebijakan Dividen Terhadap Harga Saham Perusahaan Otomotif di Bursa Efek Jakarta. Jurnal Mandiri 9 (1).

Putra, R. A. 2014. Pengaruh Profitabilitas, Struktur Modal, Nilai Perusahaan dan Likuiditas Terhadap Nilai Perusahaan (Studi pada Perusahaan Asuransi di Bursa Efek Indonesia Tahun 2010-2012). Artikel. Universitas Brawijaya. Malang.

Rais, B. N. and H. F. Santoso. 2017. Pengaruh Kepemilikan Manajerial, Kepemilikan Institusional, Profitabilitas, dan Ukuran Perusahaan Terhadap Kebijakan Dividen. Jurnal Ilmiah Manajemen Bisnis. 17 (2): 111-124.

Riyanti and A. Munawaroh. 2021. Kepemilikan Manajerial, Kepemilikan institusional, Kebijakan Dividen, Ukuran Perusahaan dan Pengaruhnya Terhadap Nilai Perusahaan. Jurnal Muhammadiyah Manajemen and Bisnis 2 (1).

Riyanto, B. 2001. Dasar-Dasar Pembelanjaan Perusahaan. Edisi Keempat. BPFE. Yogyakarta.

Rubiyani, D. 2016. Pengaruh Profitabilitas Terhadap Firm Value Dengan Capital Structure Sebagai Variabel Intervening pada Perusahaan LQ45 Yang Terdaftar di BEI. E-Journal STIESIA Surabaya 5 (4).

Rudianti, W. Y. A. Pratama, and A. Sugiarti. 2020. Pengaruh Corporate Social Responsibility, Kepemilikan Manajerial, Kepemilikan Institusional dan Kepemilikan Publik Terhadap Nilai Perusahaan. Jurnal Riset Keuangan and Akuntansi 6 (2).

Rudianto. 2009. Pengantar Akuntansi. Erlangga. Jakarta.

Safitri, O. N., S. R. Handayani, and N. F. Nuzula. 2014. The Influence Of Capital 
Structure and Profitability On Firm Value (A Study in Retail Companies Listed in Indonesia Stock Exchange 2010-2013 period).Jurnal Administrasi Bisnis (JAB) 13 (2).

Septiana, M. 2015. Analisis Pengaruh Cash Ratio, Debt to Equity Ratio, Return on Asset, Firm Size dan Growth Opportunity Terhadap Kebijakan Dividen. Skripsi. Universitas Diponegoro. Semarang.

Sitepu, C. N. 2010. Pengaruh Kinerja Keuangan Terhadap Harga Saham pada Perusahaan Industri Makanan dan Minuman yang terdaftar di BEI. Jurnal Akuntansi. Fakultas Ekonomi Universtias Sumatera Utara. Meand.

Subramanyam, K. R. 2014. Financial Statement Analysis. Eleventh Edition. McGraw-Hill Education. New York.

Sugiono, A. and E. Untung. 2016. Analisa Laporan Keuangan. Penerbit Grasindo. Jakarta. Sulistyowati, A., Suhandak, and A. Husaini. 2014. Pengaruh Struktur Modal terhadap Kebijakan Dividen pada Perusahaan yang Terdaftar di Bursa Efek Indonesia Periode Tahun 2010-2012. Jurnal Administrasi Bisnis (JAB) 8 (2): 2-10.

Suryanti, F. S. and L. Amanah. 2020. Pengaruh Profitabilitas, leverage, Free Cash Flow dan Kebijakan Dividen Terhadap Nilai Perusahaan. Jurnal Ilmu and Riset Akuntansi.

Sutanto, J., D. Marciano, and E. Ernawati. 2017. Pengaruh Kepemilikan Institudional Terhadap Kebijakan Dividen pada Perusahaan Sektor Industri Property, Real Estate, dan Konstruksi Bangunan yang Terdaftar di BEI Periode 2011-2015. Jurnal Ilmiah Mahasiswa Universitas Surabaya 6 (2): 966-981.

Widayanti, L. P. and I. P. Yadnya. 2020. Leverage, Profitabilitas dan Kepemilikan Manajerial Berpengaruh pada Nilai Perusahaan Pada Perusahaan Real Estate dan Property. E-Jurnal Manajemen 9 (2).

Widyasari, Y. 2020. Analisis Faktor-Faktor yang Mempengaruhi Nilai Perusahaan. Jurnal Paradigma Akuntansi 2 (2).

Wihardjo, D. S. 2014. Analisis Faktor-Faktor Yang Mempengaruhi Nilai Perusahaan (Studi pada Perusahaan Manufaktur yang Terdaftar di BEI Tahun 2009-2011). Skripsi. Fakultas Ekonomi and Bisnis Universitas Diponegoro. Semarang.

Wijaya, L. R. P. 2010. Implikasi Keputusan Investasi, Penandaan, dan Dividen Terhadap Nilai Perusahaan. Tesis. Universitas Sebelas Maret. Surakarta.

Wijaya, B. I. and I. B. P. Seanda. 2015. Pengaruh Profitabilitas Terhadap Nilai Perusahaan (Kebijakan Dividen dan Kesempatan Investasi Sebagai Variabel Mediasi). E-Jurnal Manajemen Universitas Udayana 4 (12): 4477-4500.

Yudistira, I. G. Y., N. P. Y. Mendar, and P. W. Saitri. 2021. Pengaruh Pertumbuhan Aset, Profitabilitas, Kepemilikan Institudional dan Kebijakan Dividen Terhadap Nilai Perusahaan. Karya Riset Mahasiswa Akuntansi 1 (1). 